\title{
LOAC: a small aerosol optical counter/sizer for ground-based and balloon measurements of the size distribution and nature of atmospheric particles - Part 2: First results from balloon and unmanned aerial vehicle flights
}

\author{
Jean-Baptiste Renard $^{1}$, François Dulac ${ }^{2}$, Gwenaël Berthet ${ }^{1}$, Thibaut Lurton ${ }^{1}$, Damien Vignelles ${ }^{1}$, Fabrice Jégou ${ }^{1}$, \\ Thierry Tonnelier $^{3}$, Matthieu Jeannot ${ }^{1}$, Benoit Couté ${ }^{1}$, Rony Akiki ${ }^{3}$, Nicolas Verdier $^{5}$, Marc Mallet ${ }^{6}$, \\ François Gensdarmes ${ }^{7}$, Patrick Charpentier ${ }^{8}$, Samuel Mesmin $^{8}$, Vincent Duverger $^{1}$, Jean-Charles Dupont ${ }^{9}$, \\ Thierry Elias ${ }^{10}$, Vincent Crenn ${ }^{2}$, Jean Sciare ${ }^{2}$, Paul Zieger ${ }^{11}$, Matthew Salter ${ }^{11}$, Tjarda Roberts ${ }^{1}$, Jérôme Giacomoni ${ }^{4}$, \\ Matthieu Gobbi $^{4}$, Eric Hamonou ${ }^{2}$, Haraldur Olafsson ${ }^{12}$, Pavla Dagsson-Waldhauserova ${ }^{12,13}$, Claude Camy-Peyret ${ }^{14}$, \\ Christophe Mazel $^{15}$, Thierry Décamps ${ }^{15}$, Martin Piringer ${ }^{16}$, Jérémy Surcin ${ }^{1}$, and Daniel Daugeron ${ }^{17}$ \\ ${ }^{1}$ LPC2E-CNRS/Université d'Orléans, 3A avenue de la recherche scientifique, 45071 Orléans, France \\ ${ }^{2}$ LSCE-CEA/IPSL/Université Paris Saclay, CEA Saclay 701, 91191 Gif-sur-Yvette, France \\ ${ }^{3}$ Environnement-SA, 111 boulevard Robespierre, BP 4513, 78304, Poissy, France \\ ${ }^{4}$ Groupe Aerophile, 106 avenue Felix Faure, 75015 Paris, France \\ ${ }^{5}$ Centre National d'Etudes Spatiales (CNES), DCT/BL/NB, 18 avenue Edouard Belin, 31401 Toulouse CEDEX 9, France \\ ${ }^{6}$ Laboratoire d'Aérologie/Université Paul Sabatier, 14 avenue Edouard Belin, 31400 Toulouse, France \\ ${ }^{7}$ Institut de Radioprotection et de Sûreté Nucléaire (IRSN), PSN-RES, SCA, Gif-sur-Yvette, 91192, France \\ ${ }^{8}$ MeteoModem, Rue de Bessonville, 77760 Ury, France \\ ${ }^{9}$ LMD/IPSL - Ecole Polytechnique, Route de Saclay, 91128 Palaiseau Cedex, France \\ ${ }^{10} \mathrm{HYGEOS} / \mathrm{LMD} / \mathrm{IPSL}$ - Ecole Polytechnique - Route de Saclay, 91128 Palaiseau CEDEX, France \\ ${ }^{11}$ Stockholm University Department of Environmental Science and Analytical Chemistry, Svante Arrhenius väg 8, \\ 11418 Stockholm, Stockholm, Sweden \\ ${ }^{12}$ University of Iceland and Icelandic Meteorological Office, Reykjavik, Iceland \\ ${ }^{13}$ Agricultural University of Iceland, Keldnaholt, Reykjavik, Iceland \\ ${ }^{14}$ IPSL (UPMC/UVSQ), 4 place Jussieu, Boîte 101, 75252 Paris CEDEX 05, France \\ ${ }^{15}$ Fly-n-Sense, 25 rue Marcel Issartier, 33700 Mérignac, France \\ ${ }^{16}$ Zentralanstalt für Meteorologie und Geodynamik, Vienna, Austria \\ ${ }^{17}$ Université d'Auvergne/LPC2E, Paul Constans, Rue Christophe Thivrier, BP 415, 03107 Montluçon CEDEX, France
}

Correspondence to: Jean-Baptiste Renard (jbrenard@cnrs-orleans.fr)

Received: 20 July 2015 - Published in Atmos. Meas. Tech. Discuss.: 28 September 2015

Revised: 9 July 2016 - Accepted: 19 July 2016 - Published: 9 August 2016

\begin{abstract}
In the companion (Part I) paper, we have described and evaluated a new versatile optical particle counter/sizer named LOAC (Light Optical Aerosol Counter), based on scattering measurements at angles of 12 and $60^{\circ}$. That allows for some typology identification of particles (droplets, carbonaceous, salts, and mineral dust) in addition to sizesegregated counting in a large diameter range from $0.2 \mu \mathrm{m}$ up to possibly more than $100 \mu \mathrm{m}$ depending on sampling con-
\end{abstract}

ditions (Renard et al., 2016). Its capabilities overpass those of preceding optical particle counters (OPCs) allowing the characterization of all kind of aerosols from submicronicsized absorbing carbonaceous particles in polluted air to very coarse particles $(>10-20 \mu \mathrm{m}$ in diameter) in desert dust plumes or fog and clouds. LOAC's light and compact design allows measurements under all kinds of balloons, on-board unmanned aerial vehicles (UAVs) and at 
ground level. We illustrate here the first LOAC airborne results obtained from a UAV and a variety of scientific balloons. The UAV was deployed in a peri-urban environment near Bordeaux in France. Balloon operations include (i) tethered balloons deployed in urban environments in Vienna (Austria) and Paris (France), (ii) pressurized balloons drifting in the lower troposphere over the western Mediterranean (during the Chemistry-Aerosol Mediterranean Experiment - ChArMEx campaigns), (iii) meteorological sounding balloons launched in the western Mediterranean region (ChArMEx) and from Aire-sur-l'Adour in south-western France (VOLTAIRE-LOAC campaign). More focus is put on measurements performed in the Mediterranean during (ChArMEx) and especially during African dust transport events to illustrate the original capability of balloon-borne LOAC to monitor in situ coarse mineral dust particles. In particular, LOAC has detected unexpected large particles in desert sand plumes.

\section{Introduction}

The concentration, size and properties of atmospheric aerosol particles are highly variable in both space and time due to the large variety of aerosol sources of both natural and manmade origin, and to their relatively short residence time in the atmosphere (Holton et al., 2003). The characterization and monitoring of aerosol particles in the lower and middle Earth atmosphere is important for climate studies (e.g. Kaufman et al., 2002; Ammann et al., 2003, respectively) and near the surface for air quality issues (e.g. Brunekreef and Holgate, 2002). When very high concentrations of ash after volcanic eruptions are present at aircraft cruise altitude (e.g. Chazette et al., 2012; Miffre et al., 2012), they can severely affect air traffic. In the middle atmosphere, aerosols also play a significant role in stratospheric ozone chemistry through heterogeneous reactions with nitrogen and halogen species (e.g. Hanson et al., 1994, 1996). To understand and predict aerosol impacts, it is important to develop observation and monitoring systems allowing for their characterization. In particular, small instruments adapted to balloon-borne measurements are scarce and generally devoted to stratospheric aerosols (Deshler et al., 2003; Renard et al., 2008). The aim of our study was to develop a new, relatively low-cost optical aerosol particle counter that could be launched under small balloons.

In Part I of this publication, a new versatile optical counter/sizer instrument named LOAC (Light Optical Aerosols Counter) was described and evaluated. It is light and compact enough to perform measurements at the surface and on-board airborne vehicles including all kinds of balloons in the troposphere and in the stratosphere and unmanned aerial vehicles (UAVs). LOAC uses a new approach combining measurements at two scattering angles, which al- lows the determination of the particle size distribution and of the dominant nature of particles (mainly liquid droplets, carbonaceous particles, mineral dust and salt particles) in various size classes.

Meteorological sounding balloons and UAVs are well adapted for regular airborne operations or on alert like during volcanic plume or strong pollution events. LOAC can be launched from different locations and can perform measurements in inaccessible places from the ground, including oceans. Measurement from balloon and UAVs can be conducted with a low relative speed between the air and the inlet, which is in favour for collecting the largest particles. Such in situ aerosols measurements can allow us to validate modelling calculations concerning the presence or not of the particles in the atmosphere, and to determine more accurately their size distribution and their main nature than from remote sensing measurements from ground and satellite. In this paper, we illustrate the first airborne results obtained with LOAC on-board a UAV and under different kinds of balloons including low-altitude tethered balloons, meteorological sounding balloons, pressurized tropospheric drifting balloons, and stratospheric balloons.

\section{LOAC instrument and gondola for balloon flights}

A first description of the instrument is given in Lurton et al. (2014) and in the first part of the paper (Renard et al., 2016). Particles are drawn up to the optical chamber though an isostatic tube by a small pump. The air stream crosses the centre of a laser beam of $25 \mathrm{~mW}$ working at the red wavelength of $650 \mathrm{~nm}$. The scattered light is recorded by two photodiodes at scattering angles of $\sim 12$ and $\sim 60^{\circ}$. Photons travel directly to the photodiodes though pipes (without a lens), providing fields of view with a few degrees. A total of 19 size classes are defined for diameters between 0.2 and $\sim 100 \mu \mathrm{m}$. The size classes are chosen as a good compromise between the instrument sensitivity and the expected size distribution of ambient air aerosols. LOAC can determine up to $\sim 3000$ particles $\mathrm{cm}^{-3}$ smaller than $1 \mu \mathrm{m}, 20$ particles $\mathrm{cm}^{-3}$ greater than $1 \mu \mathrm{m}$ in dry conditions and up to 200 particles $\mathrm{cm}^{-3}$ in fog/cloud conditions. For a 10-min integration time, the uncertainty (at $1 \sigma$ ) is of about $\pm 20 \%$ for concentrations higher than $10^{-1}$ particles $\mathrm{cm}^{-3}$ up to $\pm 60 \%$ for concentrations lower than $10^{-2} \mathrm{~cm}^{-3}$; the uncertainty for total concentrations measurements is better than $\pm 20 \%$. Also, the uncertainties in size calibration is of $\pm 0.025 \mu \mathrm{m}$ for particles smaller than $0.6 \mu \mathrm{m}, 5 \%$ for particles in the $0.7-2 \mu \mathrm{m}$ range, and of $10 \%$ for particles greater than $2 \mu \mathrm{m}$.

The measurements at $12^{\circ}$ are almost insensitive to the refractive index of the aerosol particles and are used to determine the concentrations (Renard et al., 2010a; Lurton et al., 2014). On the other hand, the measurements at $60^{\circ}$ are very sensitive to the refractive index (e.g. Muñoz and Volten, 2006). An indication of the typology of the particles is ob- 
Table 1. LOAC balloon flights illustrated in this study.

\begin{tabular}{|c|c|c|c|c|c|}
\hline Campaign & Launch location & Launch latitude and longitude & Launchdate & Balloon type & LOAC inlet \\
\hline EGU & $\begin{array}{l}\text { Vienna } \\
\text { (Austria) }\end{array}$ & $\begin{array}{l}48.2343^{\circ} \mathrm{N} \\
16.4132^{\circ} \mathrm{E}\end{array}$ & 11 April 2013 & $\begin{array}{l}\text { Tethered } \\
\text { balloon }\end{array}$ & $\begin{array}{l}\text { Metal, } \\
\text { bevelled }\end{array}$ \\
\hline OAG & $\begin{array}{l}\text { Paris } \\
\text { (France) }\end{array}$ & $\begin{array}{l}48.8414^{\circ} \mathrm{N} \\
02.2740^{\circ} \mathrm{W}\end{array}$ & 11 December 2013 & $\begin{array}{l}\text { Tethered } \\
\text { balloon }\end{array}$ & TSP \\
\hline OAG & $\begin{array}{l}\text { Paris } \\
\text { (France) }\end{array}$ & $\begin{array}{l}48.8414^{\circ} \mathrm{N} \\
02.2740^{\circ} \mathrm{W}\end{array}$ & 10 April 2014 & $\begin{array}{l}\text { Tethered } \\
\text { balloon }\end{array}$ & TSP \\
\hline ChArMEx & $\begin{array}{l}\text { Minorca } \\
\text { (Spain) }\end{array}$ & $\begin{array}{l}39.8647^{\circ} \mathrm{N} \\
04.2539^{\circ} \mathrm{E}\end{array}$ & 18 June 2013 & $\begin{array}{l}\text { Tropospheric } \\
\text { pressurized balloon }\end{array}$ & $\begin{array}{l}\text { Metal, } \\
\text { bevelled }\end{array}$ \\
\hline $\begin{array}{l}\text { VOLTAIRE- } \\
\text { LOAC }\end{array}$ & $\begin{array}{l}\text { Aire-sur-l'Adour } \\
\text { (France) }\end{array}$ & $\begin{array}{l}43.702^{\circ} \mathrm{N} \\
0.262^{\circ} \mathrm{W}\end{array}$ & 12 August 2015 & $\begin{array}{l}\text { Meteorological } \\
\text { balloon }\end{array}$ & $\begin{array}{l}\text { Metal, } \\
\text { bevelled }\end{array}$ \\
\hline
\end{tabular}

tained using the "speciation index", retrieved by combining the 12 and $60^{\circ}$ channels measurements. This index is mainly sensitive to the imaginary part of the index, thus to the absorbing properties of the particles. Speciation zones have been determined with LOAC in laboratory for four types of particles: solid carbonaceous, mineral dust, salt particles, and liquid droplet. The carbon speciation zone is larger than the other ones because the scattered-light properties of such particle depends also on their shape and their composition (organics vs. soot). The speciation indices obtained from LOAC observations in the atmosphere are compared to the speciation zones obtained in the laboratory to derive the typology of dominant particles in different size classes. The position of the data points in the various speciation zones provides the main nature of the particles (it is recommended to consider the trend of the curve rather than considering individual points separately). The identification of the nature of the particles works well in the case of a homogenous medium, and is more difficult in the case of a heterogeneous medium that generally cause the speciation index to be scattered among several speciation zones.

To minimize the instrument weight, the optical chamber is in plastic Delrin ${ }^{\circledR}$. The weight, including the pump, is of $300 \mathrm{~g}$. The electric consumption is of $340 \mathrm{~mA}$ under $8 \mathrm{~V}$, which corresponds to $3 \mathrm{~W}$. Autonomy of about $3 \mathrm{~h}$ can be obtained with alkaline batteries. A gondola in polystyrene has been developed for flights under meteorological balloon. The data are sent in real-time by on-board telemetry. In its nominal configuration, LOAC uses the MeteoModem Company system for telemetry and GPS, and for temperature, pressure and humidity (PTU) measurements (http: //www.meteomodem.com/). The total weight of the gondola (Fig. 1a), including the batteries and the PTU sounding, is of about $1 \mathrm{~kg}$; its size is $28 \times 18 \times 15 \mathrm{~cm}^{3}$. The inlet is almost vertically oriented towards the sky. The duration of a flight with meteorological balloons is of about $2 \mathrm{~h}$, and can reach an altitude of $37 \mathrm{~km}$ with a latex balloon of $1200 \mathrm{~g}$. One of the critical parts of the instrument is the pumping system, which must work in extreme conditions in the middle atmosphere. At the ground level, the pump has a stability of about
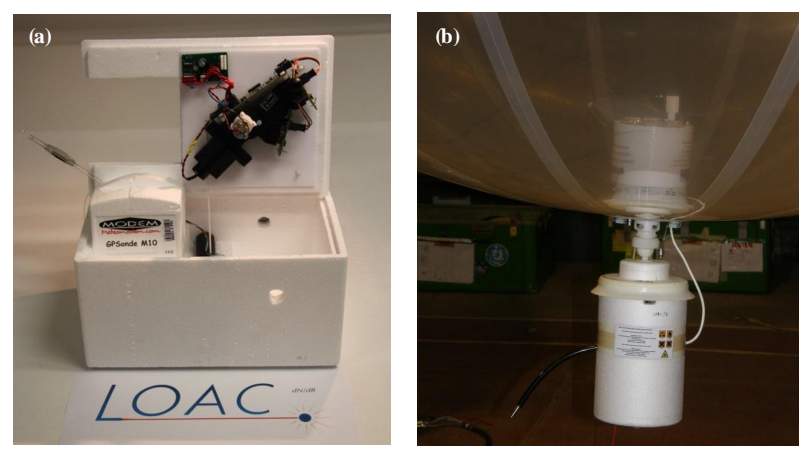

Figure 1. (a, left) The LOAC gondola with a Meteomdem Company sonde for flight under meteorological balloons; (b, right) the LOAC gondola below a low troposphere drifting balloon.

$\pm 5 \%$. Tests have been conducted in the stratosphere during a meteorological flight up to an altitude of $34 \mathrm{~km}$. The rotation speed of the pump and its stability were the same all along the flight, allowing us to conclude that the pump is insensitive to temperature and pressure variations.

A specific gondola has been developed for launch below low altitude drifting balloons developed by the French Space Agency (CNES; Fig. 1b). In this case, the inlet was horizontally oriented, to avoid the contamination from the balloon. Such tropospheric balloons can stay in flight at a float altitude below $3500 \mathrm{~m}$ over several tens of hours (Ethé et al., 2002).

\section{Field measurements under UAV and balloons}

\subsection{General comments}

A large number of LOAC flights under different kinds of balloons and airborne vehicles has been conducted since 2011. We present here some examples of the flight results (Table 1) and first interpretations of the measurements.

For all kinds of free short flights, the measurements were not conducted in the balloon wake, preventing contamination. Some flights under drifting and sounding balloons were 
conducted with a very good time and spatial coincidence (less than $1 \mathrm{~h}$ and less than $50 \mathrm{~km}$ ). Both measurements at the same altitude are in good agreement, confirming that no pollution cloud was around the drifting balloon.

During ground-based and flight tests, no effect of pressure and humidity on the LOAC working was detected. Nevertheless, laboratory tests have shown that there is a risk of condensation or ice on the detectors in the case of rapid decreasing of temperature at thigh humidity level. Condensation or ice would produce strong stray-light contamination, and the data would be rejected. But because humidity is low in the tropopause region and in the stratosphere, these problems will not occur. They could occur only inside thick tropospheric clouds (in general the balloon will not operate or survive in such extreme environment).

The penetration efficiency in the inlet of particles larger than typically several $\mu \mathrm{m}$ could depart significantly from $100 \%$, depending on the sampling condition. As shown in part 1 of the paper, the efficiency could be above $100 \%$ during flight under meteorological balloon when the inlet is oriented towards the sky. The efficiency is probably close to $100 \%$ when the relative speed between the inlet and the air is close to zero, as encountered during flight under drifting balloons. The efficiency is probably underestimated during ground-based measurements or during tethered balloons measurements, depending on the wind speed and on the kind of inlet used. This problem will need further studies, in particular for the analysis of the concentrations of particles greater than the $\mathrm{PM}_{10}$.

\subsection{Unmanned aerial vehicle flights}

A possible application of LOAC consists in measurements from unmanned aerial vehicles. LOAC has been mounted on a small UAV of Fly-n-Sense Company (Fly-n-Sense, http://www.fly-n-sense.com/uav-solutions/environment/), as shown on Fig. 2. The sampling is performed by a vertical inlet, in a non-turbulent zone of the UAV environment. Laboratory tests have been conducted to ensure, first, that the sampled air is indeed not affected by the motions of the propellers, and secondly that the electromagnetic radiations of the motors do not perturb the LOAC electronics. Figure 3 presents an example of a 20-min flight close to the ground performed in a field near the Bordeaux-Mérignac airport (south-west of France; $49^{\circ} 49^{\prime} 43^{\prime \prime} \mathrm{N}, 0^{\circ} 42^{\prime} 55^{\prime \prime} \mathrm{W}$ ) on $18 \mathrm{De}-$ cember 2013 at 14:30 UT. The total concentration of particles larger than $0.2 \mu \mathrm{m}$ in diameter is between 100 and 1000 particles $\mathrm{cm}^{3}$. Large particles up to $20 \mu \mathrm{m}$ in diameter were observed all flight long and larger particles (up to the last channel $40-50 \mu \mathrm{m}$ ) were regularly counted, indicating that indeed large particles can be collected. The LOAC typology indicates mainly carbonaceous particles for the smallest size with the presence of some mineral particles as expected in such a location (e.g. Karagulian et al., 2015).

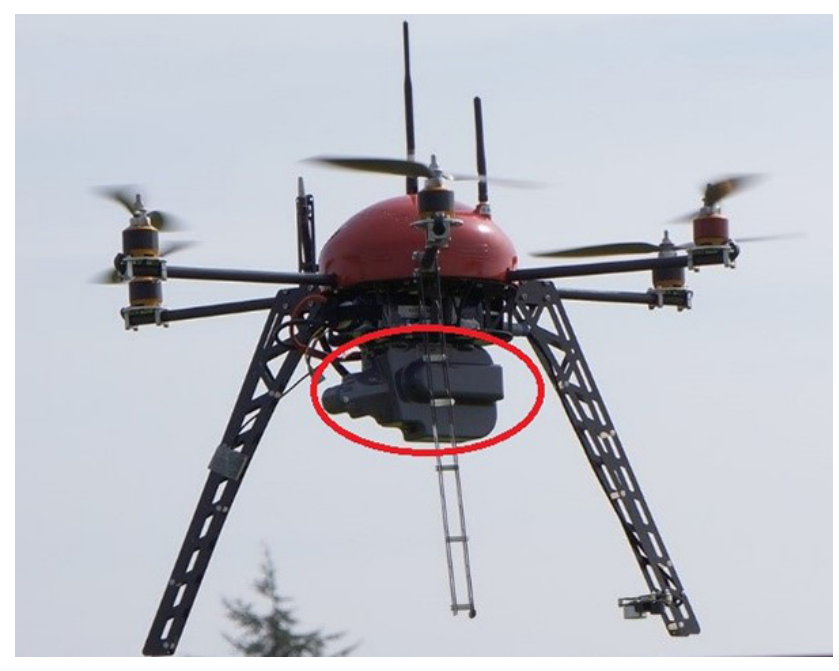

Figure 2. LOAC on board an unmanned aerial vehicle of the Fly $\mathrm{N}$ Sense Company; LOAC is on the black box at the bottom of the vehicle (red circle).

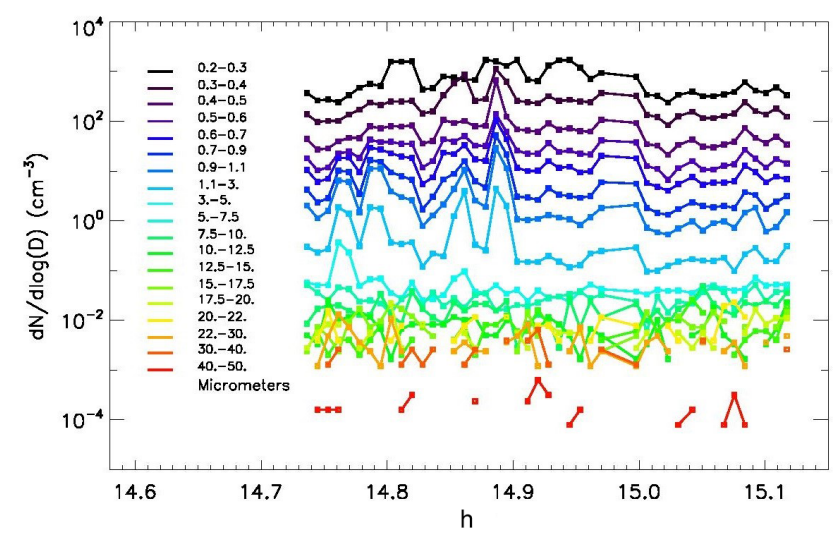

Figure 3. Aerosol particle size distribution from LOAC flight onboard an unmanned aerial vehicle flown close to the surface in periurban conditions near Bordeaux-Mérignac (France) on 18 December 2013 at 14:30 UT; the uncertainty (at $1 \sigma$ ) is of about $\pm 20 \%$ for concentrations higher than $10^{-1} \mathrm{~cm}^{-3}$ up to $\pm 60 \%$ for concentrations lower than $10^{-2} \mathrm{~cm}^{-3}$.

Because of their mobility and the possibility of stationary flights in the lower troposphere, the use of an UAV can be useful for the characterization of specific events like (local) pollution sources.

\subsection{Tethered balloons}

LOAC has been operated at two different places, in the cities of Vienna, Austria, and Paris, France, using a small and a large tethered balloon, respectively. Four flights under a $6 \mathrm{~m}^{3}$ tethered balloon were performed by the Austrian Meteorological Office (Zentralanstalt für Meteorologie und Geodynamik) during the General Assembly of the European Geosciences Union between 9 and 11 April 2013, in the square 


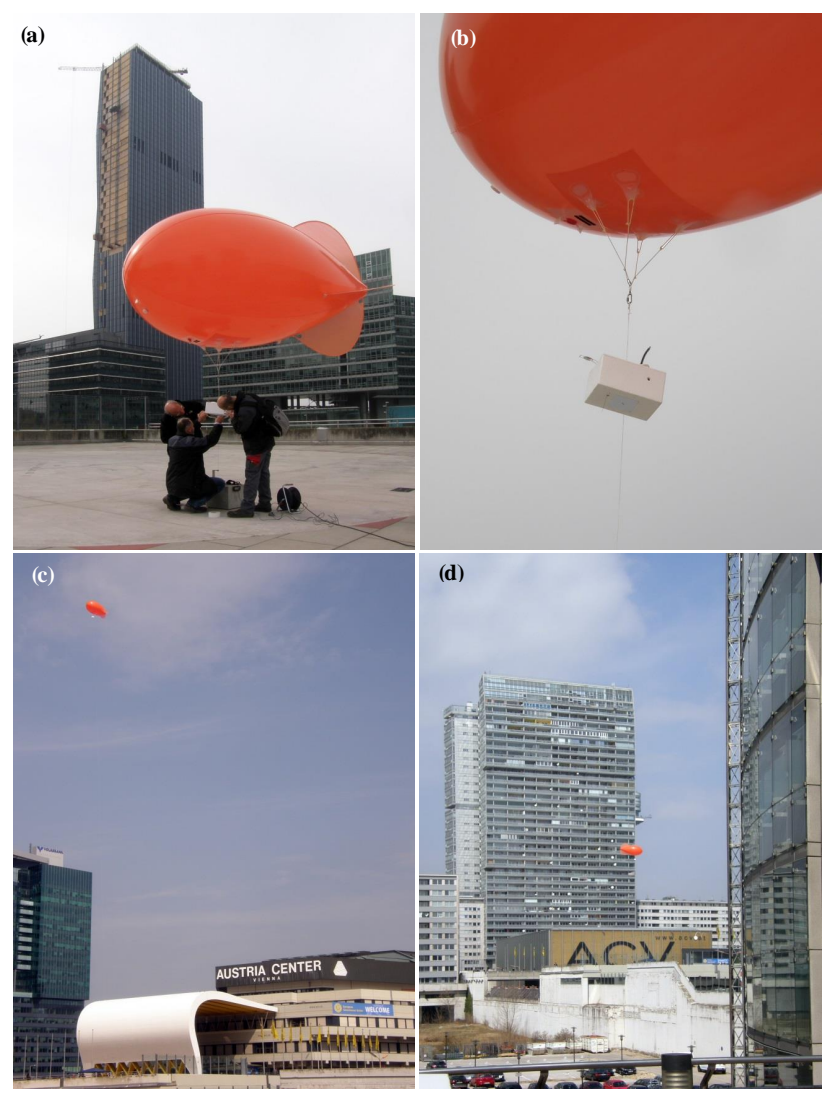

Figure 4. Pictures of the LOAC operations below a $6 \mathrm{~m}^{3}$ tethered balloon at the Austria Center in Vienna during the 2013 European General Assembly. From left to right and top to bottom: (a) preparation of the launch with a view towards the south on a tower under final stage of construction in the back; (b) view from below of LOAC in flight with its sampling inlet pointing upward; (c) view from the $\mathrm{S}$ of the balloon over the conference centre; (d) view from the south-west of the environment of the launch site including leaving and office tower blocks and an open air car park.

of the Austria Center (conference centre) in Vienna, Austria, up to an altitude of $220 \mathrm{~m}$ (position in Table 1; photos in Fig. 4). Figure 5 presents the vertical concentration profile for the 19 particle size classes during the balloon ascent on 11 April 2013 at 11:00 UT. The atmosphere content of solid particles on the ground was low with a total concentration of particles larger than $0.2 \mu \mathrm{m}$ of the order of few hundred of particles $\mathrm{cm}^{-3}$. Submicronic-sized particles dominated and were observed at all levels, and particles larger than $3 \mu \mathrm{m}$ and up to more than $10 \mu \mathrm{m}$ in diameter were often detected. The general trend is a decrease of concentrations with increasing altitude, the concentration of submicronic particles being 4 times smaller at altitude $>200 \mathrm{~m}$ than at ground. A small concentration enhancement in small particles is detected between 60 and $110 \mathrm{~m}$. The typology analysis (Fig. 6) could indicate a mixture of carbonaceous and mineral particles from the ground up to below $200 \mathrm{~m}$ (but the interpretation of the

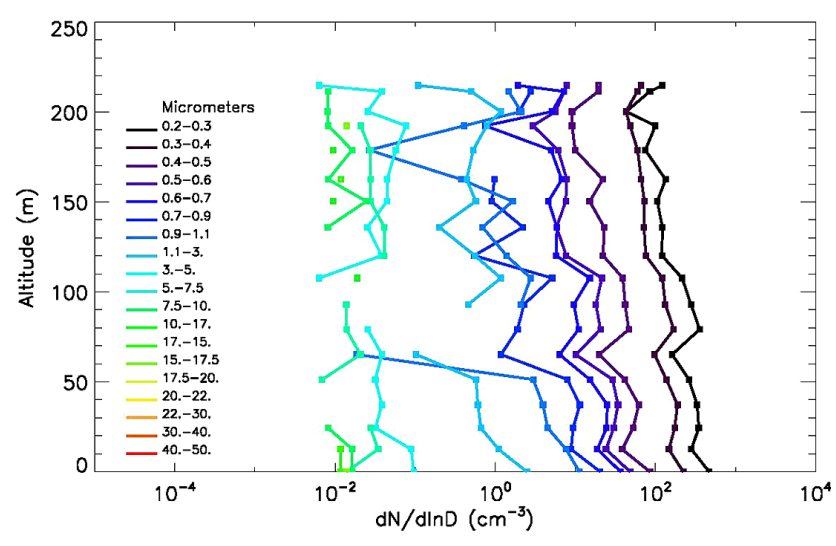

Figure 5. Evolution of the concentrations for the 19 size classes of LOAC, during a flight under a tethered balloon in Vienna (Austria) on 11 April 2013 at 11:00 UT; the uncertainty (at $1 \sigma$ ) is of about $\pm 20 \%$ for concentrations higher than $10^{-1} \mathrm{~cm}^{-3}$ up to $\pm 60 \%$ for concentrations lower than $10^{-2} \mathrm{~cm}^{-3}$.

speciation index is difficult here). Mineral particles seem to dominate at the altitude of the concentration enhancement $(\sim 80 \mathrm{~m})$, probably emitted by construction going on in a tower located $\sim 250 \mathrm{~m}$ from the balloon (Fig. 4a). Above $200 \mathrm{~m}$, only carbonaceous particles were detected, probably coming from traffic and lifted from ground by convection, confirming the likely very local origin of the mineral particles at intermediate altitude.

Permanent measurements have been conducted at the "Observatoire Atmosphérique Generali" (OAG) in the southwest of Paris since May 2013 (position in Table 1). This observatory is a recreational $6200 \mathrm{~m}^{3}$ tethered balloon (Fig. 7) operated in the public park André Citroën. The LOAC pump operates at $2.7 \mathrm{Lmin}^{1}$ and sampling is performed though a total suspended particulate (TSP) inlet vertically oriented, having a diameter cut-off at about $100 \mu \mathrm{m}$. The instrument is installed in a small ventilated metallic box fixed on the side of the balloon passenger gondola with its TSP sampling inlet pointing up. The data can be sorted out between measurements when the balloon is at ground level and measurements when the balloon is in flight. From 150 to 200 days $\mathrm{yr}^{-1}$ are favourable for flying this type of tethered balloon. The balloon measurements nominal maximum altitude is $120 \mathrm{~m}$ and many flights can be performed per day depending on wind conditions. Up to several flights per week can also be conducted with measurements up to an altitude of $270 \mathrm{~m}$. The aim of these flights is to study the possible evolution of the nature and size of particles as a function of altitude, and to distinguish between local sources at ground level and the persistent urban pollution in the middle of the boundary layer.

Since the beginning of the measurements, the air was mostly vertically mixed and the concentrations were almost constant with increasing altitude for particles smaller than $\sim 10 \mu \mathrm{m}$. Figure 8 (top) presents an example of such situation during a low level of pollution, on 10 April 2014 

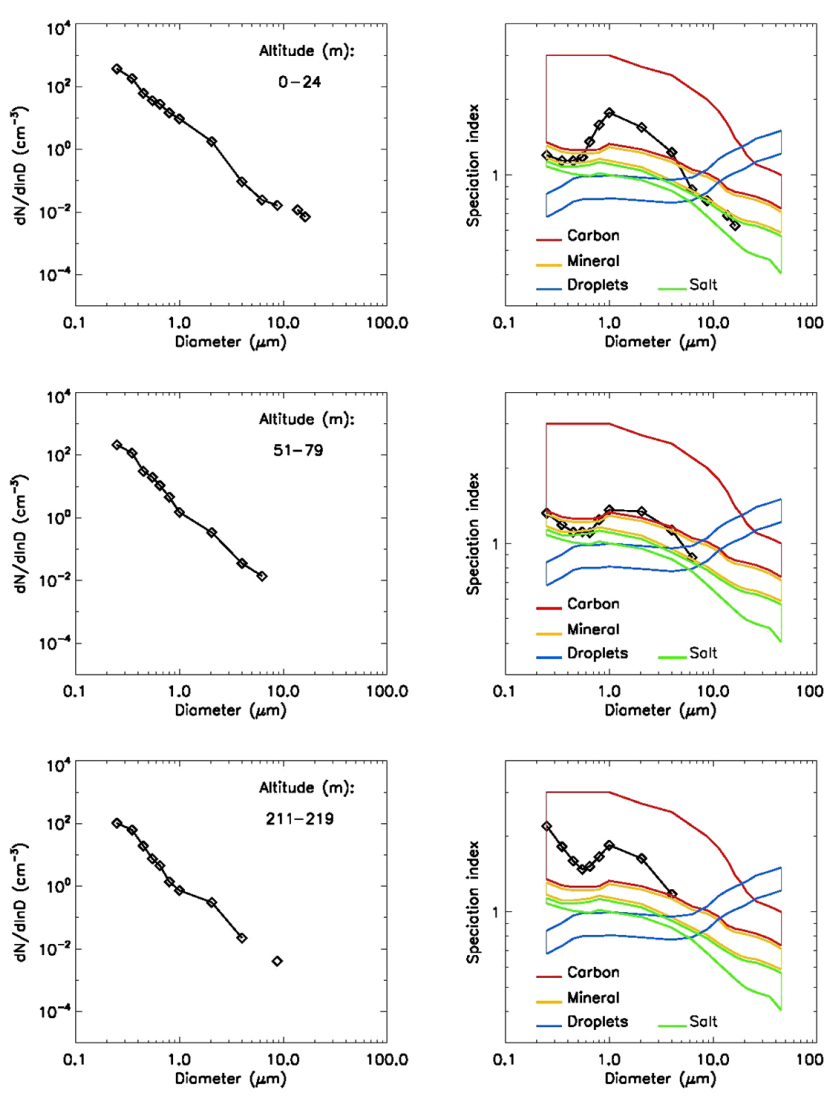

Figure 6. Size distribution and typology at three altitudes during a flight under a tethered balloon in Vienna on 11 April 2013 at 11:00 UT; the uncertainties for concentrations are the same as in Fig. 5; the sizes of the dots represent the error bars for the typology. A mixture of carbonaceous and mineral particles is detected from the ground, mineral particles dominate for the concentration enhancement at $\sim 80 \mathrm{~m}$, probably emitted from the construction of a nearby tower; above $200 \mathrm{~m}$, carbonaceous particles dominate only.

(day no. $=100$ ). Contrastingly, some flights conducted during pollution events exhibit different trends. As an example, the 11 December 2013 (day no. 345) morning flight performed during anticyclonic conditions presents a temperature inversion layer at an altitude of $\sim 200 \mathrm{~m}$, as shown on Fig. 8 (bottom). A strong accumulation layer is detected between 180 and $220 \mathrm{~m}$ and was visually confirmed by the pilot of the balloon. The total concentration of particles larger than $0.2 \mu \mathrm{m}$ in diameter is more than 1000 particles $\mathrm{cm}^{-3}$. Also, a smaller accumulation layer of particles is detected between 30 and $90 \mathrm{~m}$. The size distribution at three different altitudes (Fig. 9) shows that the atmosphere content is dominated by the smallest particles. Also, the mass concentrations (calculation method is presented in the paper 1) are dominated by the small particles, in comparison with the 10 April 2014 measurements (Fig. 10). The typology indicates a mixture of carbonaceous and mineral particles close to the ground in the recreation park, and only carbonaceous particles for the
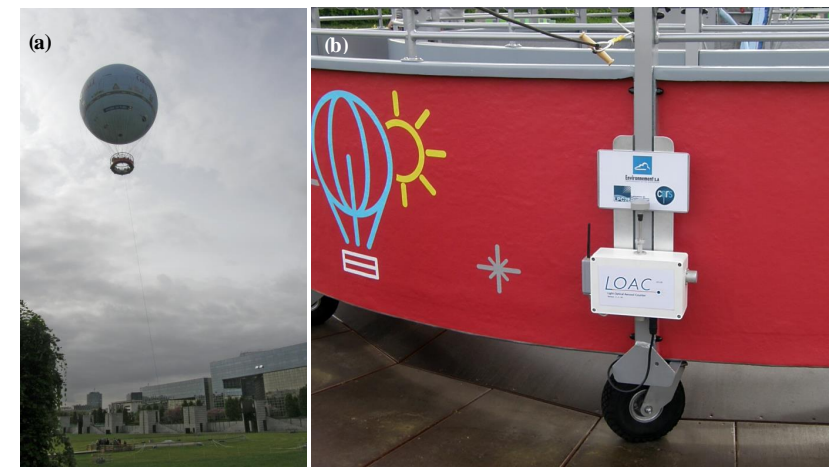

Figure 7. LOAC on the recreational OAG tethered balloon in Parc André Citroën, Paris. (a) View on the balloon in flight; (b) view of the LOAC installed in a small box on the side of the passenger gondola with its TSP inlet above, a small WiFi antenna on the left of the box for data transmission, and a ventilation opening protection (grey) on the right.

highest altitudes. The analyses of flights performed later during that day and in the following days show the progressive disappearance of the accumulation layers, correlated with changes in the meteorological conditions. It was then possible to study from in situ measurements the time evolution of the vertical distribution of the particles.

The Vienna and OAG examples show the LOAC ability to perform measurements under a tethered balloon, in order to document the size, the nature and the evolution of the particles as a function of altitude in the urban polluted boundary layer. In particular, such kind of flights can help distinguishing between local sources of pollution close to ground and accumulation/transport of aerosols in the ambient air at higher altitude in the atmospheric boundary layer.

\subsection{ChArMEx tropospheric flights with drifting balloons}

LOAC was also intensively involved in the ChArMEx project (Chemistry Aerosol Mediterranean Experiment, http: //charmex.lsce.ipsl.fr/). ChArMEx aims at a scientific assessment of the present and future state of the atmospheric environment over the Mediterranean basin (e.g. Menut et al., 2014; see ChArMEx Special Issue in Atmos. Chem. Phys. and Atmos. Meas. Tech.). All the LOAC balloon flights have been performed by the Centre National d'Etudes Spatiales (CNES).

A total of 13 LOAC flights under low tropospheric pressurized drifting balloons were conducted from the Spanish Minorca Island from 15 June to 2 July 2013, and from the French Levant Island from 22 July to 4 August 2013 (station positions in Table 1), mainly during well-identified desert dust transport events. Results will be detailed in a forthcoming paper. We illustrate here one flight launched from Minorca Island during the ChArMEx/ADRIMED (Aerosol Di- 

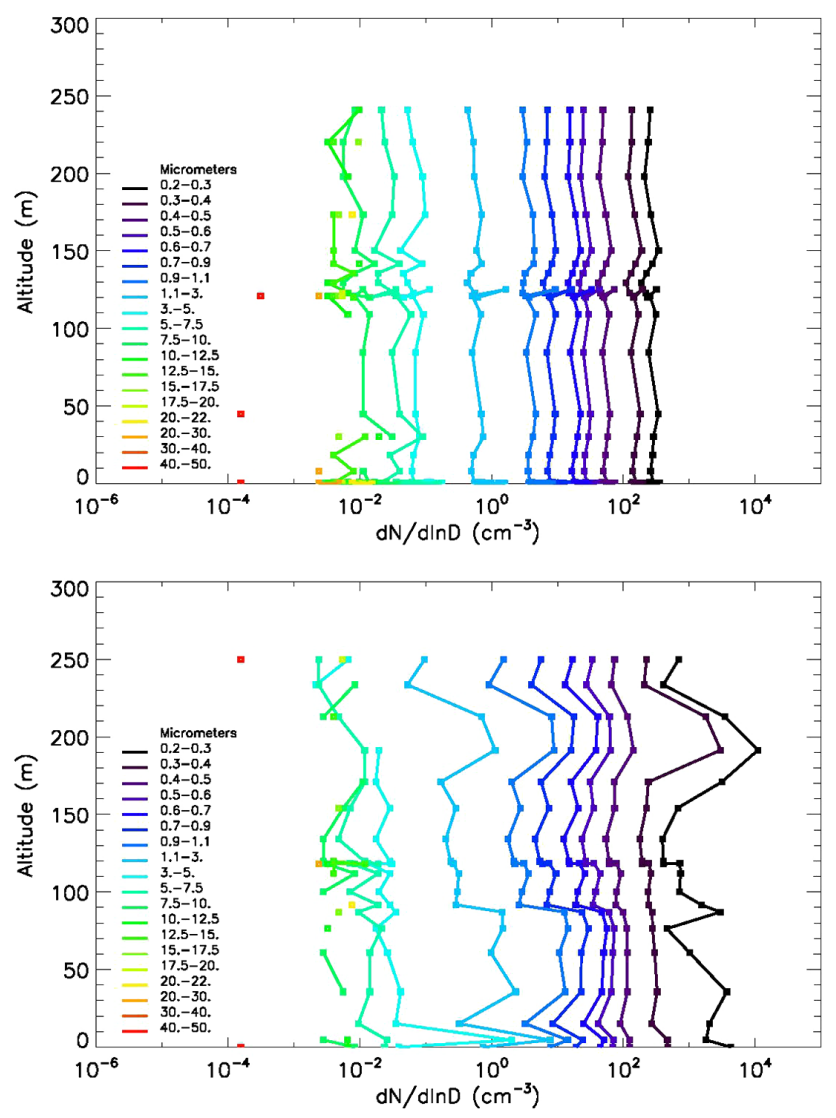

Figure 8. Evolution of the concentrations for the 19 size classes of LOAC, during a flight under the OAG tethered balloon in Paris (France); top: on 10 April 2014 at 9:15 UT (low level of pollution); bottom: on 11 December 2013 at 10:15 UT with a high level of fine particles pollution and an accumulation layer at an altitude of $200 \mathrm{~m}$; the uncertainty (at $1 \sigma$ ) is of about $\pm 20 \%$ for concentrations higher than $10^{-1} \mathrm{~cm}^{-3}$ up to $\pm 60 \%$ for concentrations lower than $10^{-2} \mathrm{~cm}^{-3}$.

rect Radiative Impact in the Mediterranean) campaign (Mallet et al., 2016). Except in the case of precipitation or condensation, these balloons follow a near-Lagrangian trajectory, i.e. remaining in the same air mass during their trajectory in the lower atmosphere, following ambient wind directions and speeds. Their float altitude was chosen before the flight in the $400-3500 \mathrm{~m}$ range by adjusting the balloon density with helium, depending on the altitude of the targeted aerosol layer. Those balloons are derived from the $2 \mathrm{~m}$ superpressure balloon model used by Ethé et al. (2002). They are spherical with a diameter of $2.5 \mathrm{~m}$ (Fig. 11a). The control and transmission gondola is placed inside the envelope at the north pole of the balloon, (Fig. 11b). For permitting flights at $3 \mathrm{~km}$ altitude or more, slightly larger balloons ( $2.6 \mathrm{~m}$ in diameter) were launched unpressurized to limit internal pressure in the balloon envelope at float altitude. A piece of aluminium foil was sometimes affixed to the outside of the balloon (Fig. 11c) to repel water from the envelope surface; this helped to solve
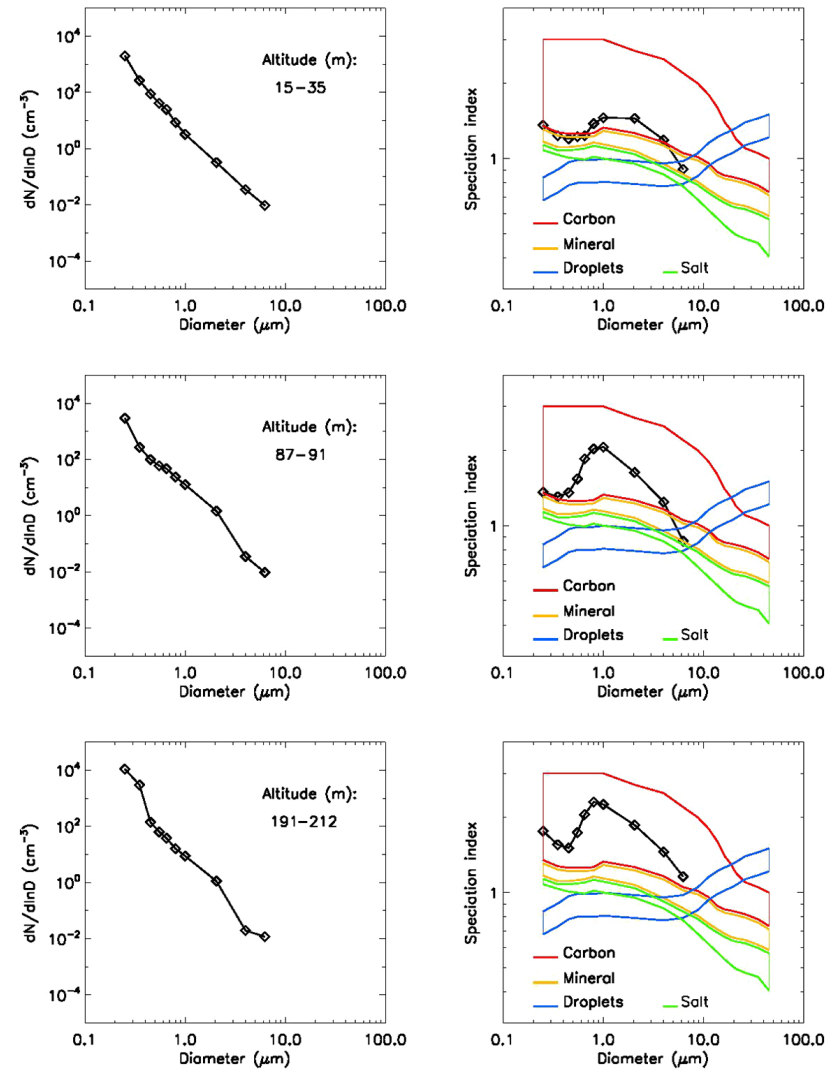

Figure 9. Size distribution and typology at three altitudes during a flight under the OAG tethered balloon in Paris (France) on 11 December 2013 at 10:15 UT; the uncertainties for concentrations are the same as in Fig. 8; the sizes of the dots represent the error bars for the typology. A mixture of carbonaceous and mineral particles is detected close to the ground in the recreation park, while only carbonaceous particles are present for the highest altitudes.

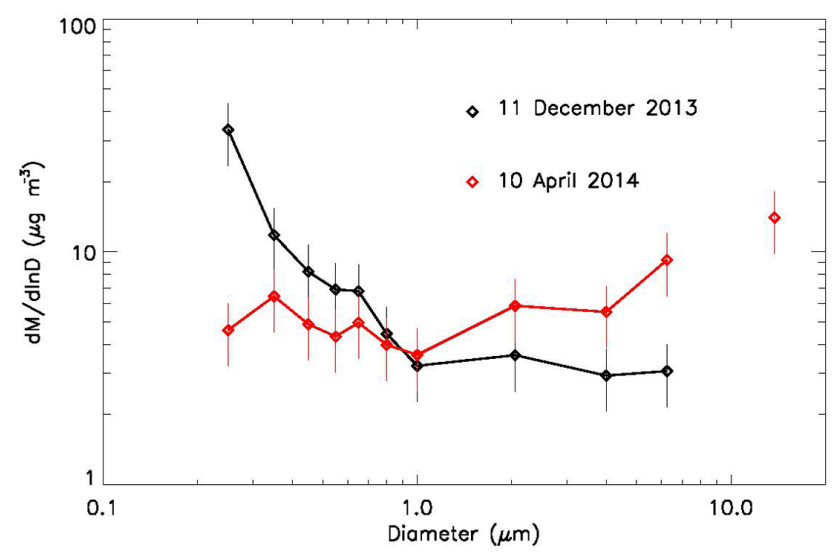

Figure 10. Comparison of the mass concentration distribution for the strong pollution event on 11 December 2013 and for the low pollution conditions on 10 April 2014; the measurements are at ground. 

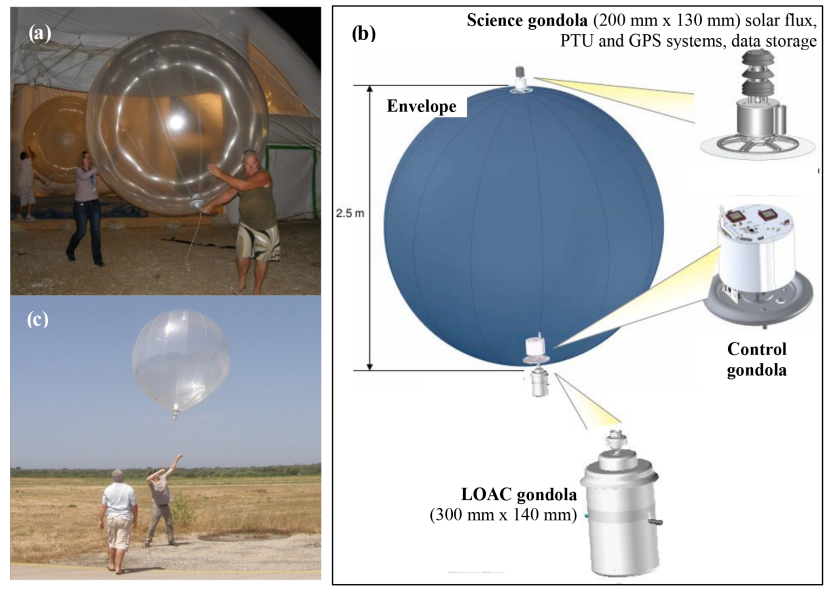

Figure 11. (a) CNES $2.5 \mathrm{~m}$ tropospheric pressurized balloon shortly before a night launch; (b) scheme of the pressurized balloon and gondolas; the scientific and control gondolas communicate by radio; (c) launch of balloon from Minorca on 17 June 2013, 9:45 UT.

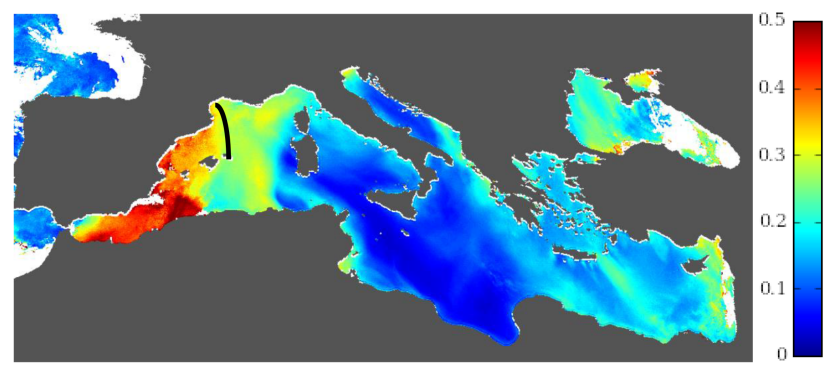

Figure 12. Daytime average aerosol optical depth at $550 \mathrm{~nm}$ derived from MSG/SEVIRI following Thieuleux et al. (2005); browse image courtesy ICARE/LSCE based on MSG/SEVIRI Level-1 data provided by Eumetsat/Eumetcast/LOA). The LOAC balloon trajectory is in black.

communication problems attributed to electrostatic charge, especially encountered with balloons that were not pressurized when launched. A hydrophobic coating may also be applied to the envelope to reduce weight due to water buildup. LOAC is fixed to the south pole of the balloon with its bevelled metallic inlet pointing on the side of its small gondola.

During these balloon flights, in which the drifting speed of the balloon was close to zero relative to ambient air, the particle sampling efficiency should be unbiased, whereas sampling on-board an aircraft generally causes a cut-off diameter of a few $\mu \mathrm{m}$ at best due to high speed (e.g. Wendisch et al., 2004; Formenti et al., 2011). This should allow for good sampling by the balloon-borne LOAC of large particles, which dominate the mass flux of mineral dust transport and deposition (e.g. Dulac et al., 1987, 2002; Foret et al., 2006). This was one of the main reasons to deploy LOAC under drifting balloons during ChArMEx campaigns.

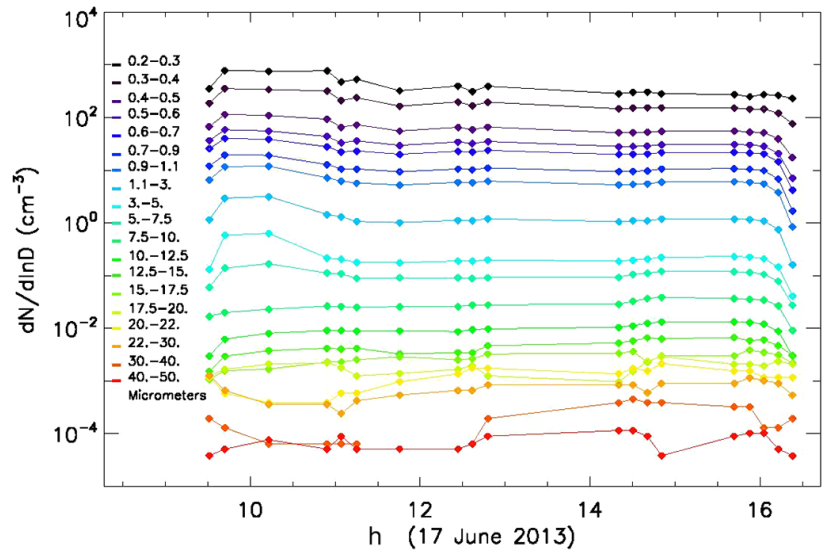

Figure 13. LOAC measurements inside a dust plume under the low tropospheric pressurized balloon during the ChArMEx campaign from Minorca, towards French coasts on 17 June 2013; the altitude was of $2000 \mathrm{~m}$; the uncertainty (at $1 \sigma$ ) is of about $\pm 20 \%$ for concentrations higher than $10^{-1} \mathrm{~cm}^{-3}$ up to $\pm 60 \%$ for concentrations lower than $10^{-2} \mathrm{~cm}^{-3}$. No obvious sedimentation of the particles was detected during the flight.

The integration time was chosen between 1 and $20 \mathrm{~min}$. This choice was imposed by the low telemetry rate for the downlink of the LOAC measurements through the Iridium satellite communication system. Also, LOAC was sometimes temporarily shut down after a short session of measurements to conserve on-board energy.

Figure 12 presents an example of balloon trajectory from Minorca between about 09:45 and 16:15 UT on 17 June 2013, during a Saharan dust transport event. The length of the flight was $360 \mathrm{~km}$ at an altitude of $2000-2050 \mathrm{~m}$. The daytime average aerosol optical depth at $550 \mathrm{~nm}$ derived from satellite MSG/SEVIRI shows values of about 0.3 along the balloon trajectory (Fig. 12), confirming the presence of dust particles in the troposphere. Figure 13 presents the evolution of the aerosol particle concentrations for the 19 size classes as a function of time along the trajectory. LOAC has detected unexpected significant concentrations of large particles inside the soil dust plume, up to $50 \mu \mathrm{m}$ in diameter. The mineral nature of the particles was confirmed by the typology measurements. The variation of concentrations of these particles is coming from the Poisson statistics, and from natural variations in the case of very low concentrations. A good estimate of their mean concentrations can be obtained by averaging (or integrating) the measurements over a longer time period. The shape of the average size distribution is similar with other counting measurements performed from aircrafts (Ryder et al., 2013; Weinzierl et al., 2011; Denjean et al., 2016), although the concentrations can be different because the measurements were not conducted in the same plume events. At least two modes were detected, one centred below $0.2 \mu \mathrm{m}$ and the second one centred at around $5 \mu \mathrm{m}$. These 


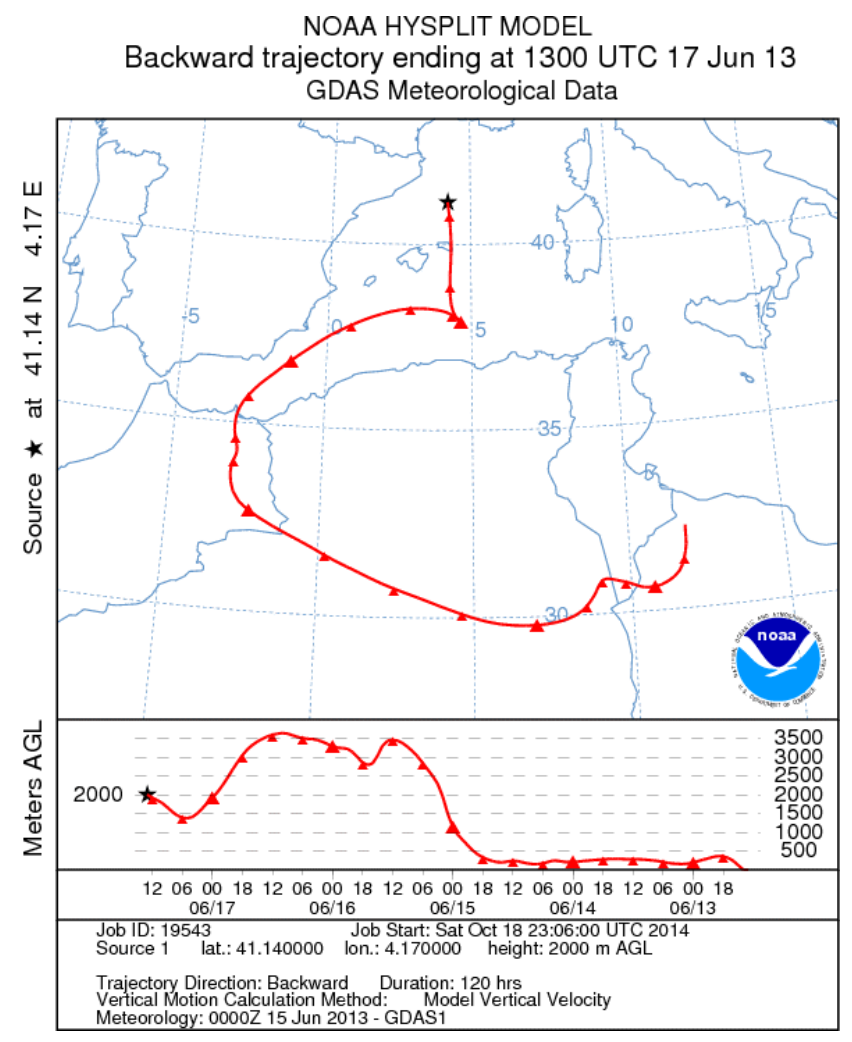

Figure 14. HYSPLIT air mass backward trajectory for LOAC balloon B75 (courtesy of NOAA Air Resources Laboratory).

similarities could be due to the production mechanism from which the plumes originated.

The plume originated from northern Africa about 3 days prior (Fig. 14). Thermal anomalies from MSG/SEVIRI North Africans Sand Storm Survey (http://nascube.univ-lille1.fr/ cgi-bin/NAS3.cgi) indicate that the dust layer sampled by the balloon was likely emitted on 14 June in the north-west Algeria-north-east Morocco source region particularly active in summer (Bergametti et al., 1989). Qualitatively, taking into account the error bars, the concentrations of the largest particles $(>20 \mu \mathrm{m})$ remained relatively constant during the flight (Fig. 13), suggesting no significant sedimentation of large particles during the flight or a compensation of particles sedimenting in the layer below by particles sedimentation from layers above. This type of observation was found during other LOAC flights, and will need further analysis in a forthcoming paper to better understand the process that can maintain such large particles in suspension over several days.

This example shows, for the first time, the time evolution of tropospheric aerosol concentrations at constant altitude $(2000 \mathrm{~m})$ from long duration balloons.

\subsection{Upper tropospheric and stratospheric flights}

Thanks to its light weight and small electric consumption, LOAC can be launched under meteorological sounding bal-

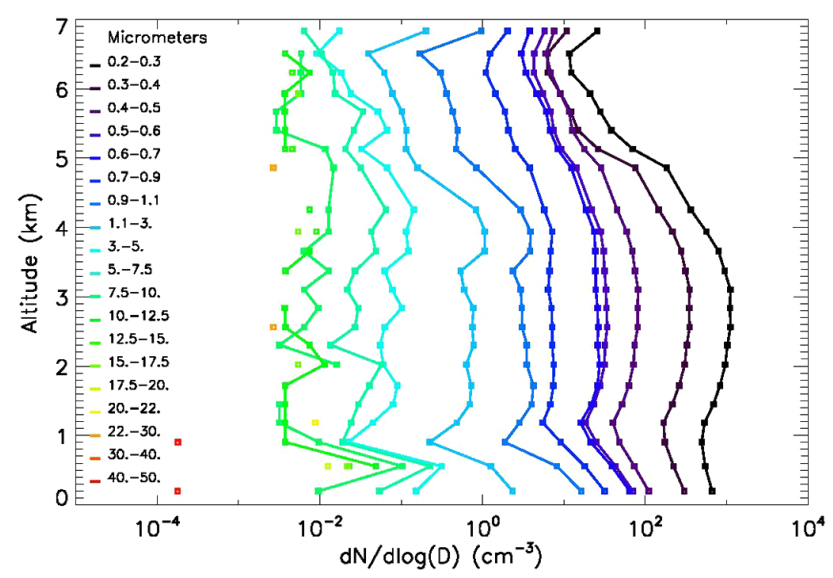

Figure 15. LOAC flight under a meteorological balloon from Minorca (Spain) on 18 June 2013 between 16:30 and 17:00 UT during the ChArMEx campaign, inside a Saharan dust plume event; the uncertainty (at $1 \sigma$ ) is of about $\pm 20 \%$ for concentrations higher than $10^{-1} \mathrm{~cm}^{-3}$ up to $\pm 60 \%$ for concentrations lower than $10^{-2} \mathrm{~cm}^{-3}$.

loons, allowing a large number of flights from different places. The measurements are conducted during the ascending phase of the balloon. The inlet is oriented toward the sky, thus towards the relative wind direction due to the ascent of the balloon at $\sim 5 \mathrm{~m} \mathrm{~s}^{-1}$. In the May 2013-December 2015 period, LOAC has performed 80 flights under meteorological balloons from France (Aire-sur-l'Adour, south-west of France; Ury, south-west of Paris region; Levant Island, south of France; and Ile de la Réunion, tropic of Capricorn), from Spain (Minorca Island) and from Iceland (Reykjavik). The highest altitude reached by LOAC with this kind of balloon is $37 \mathrm{~km}$. LOAC has passed though clouds several time and was not affected by them, with the exception of one incident when the balloon was destroyed inside a cumulonimbus cloud. In the case of measurements inside cirrus clouds, the concentrations of the smallest sizes can be underestimated due to optical shadow effect (large particles masking the smallest ones), as explained in the Sect. 2.3 of the first paper.

During the ChArMEx campaign, a total of 19 launches have been conducted from Minorca (Spain) and Levant Island (France). In particular, flights were conducted every $12 \mathrm{~h}$ between 15 and 19 June 2013, to observe the vertical distribution and the time evolution of the desert dust plume concentrations in the troposphere. Figure 15 presents the flight conducted from Minorca (Spain) on 18 June 2013 between 16:30 and 17:00 UT (only the part of the flight inside the plume is presented here). A mineral dust plume was detected in the lower troposphere up to an altitude of $5 \mathrm{~km}$, with a strong enhancement of aerosol concentrations. The typology analysis confirms the mineral nature of the particles (Fig. 16, top), while mainly carbonaceous particles dominate the aerosol content just above the dust plume layer (Fig. 16, bottom). 

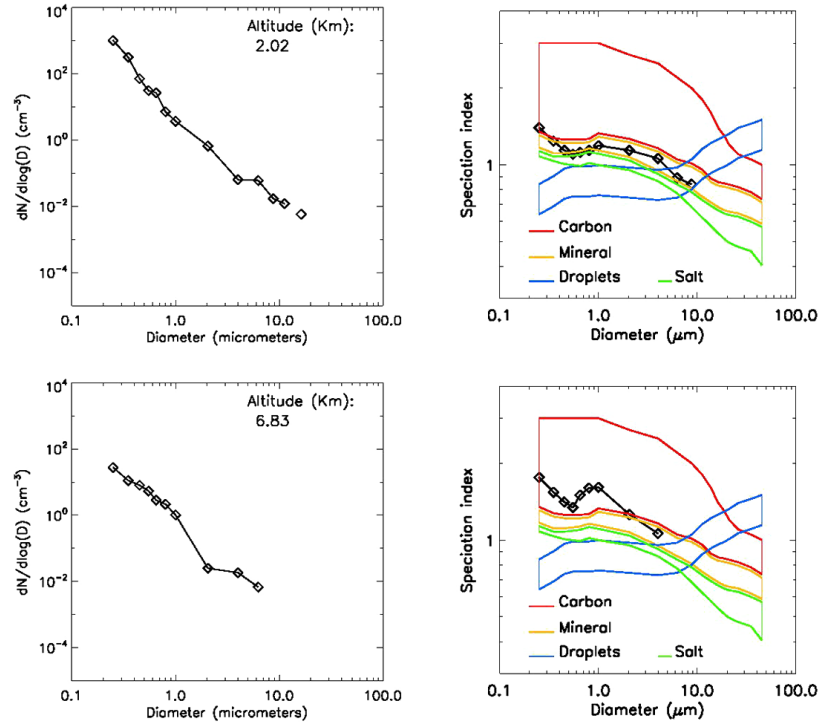

Figure 16. Examples of size distributions and typology at two altitudes for the 18 June 2013 flight from Minorca (Spain); the uncertainties for concentrations are the same as in Fig. 15; the sizes of the dots represent the error bars for the typology. At an altitude of $\sim 2 \mathrm{~km}$ the typology indicates mineral particles; at $\sim 7 \mathrm{~km}$, the typology indicates carbonaceous particles for the smallest size.

Another example of a meteorological flight is presented in Fig. 17. The flight was conducted during the VOLTAIRELOAC campaign of regular measurements for establishing a stratospheric aerosol climatology at different latitudes. The flight was performed at the French Space Agency (CNES) launching base at Aire-sur-l'Adour (south-west of France) on 17 April 2014 between 8:40 and 10:20 UT. Close to the ground, the typology indicate light fog, confirmed by the PTU sensors on board the LOAC gondola. In the upper layer, the profile exhibits a typical situation for the vertical distribution of background stratospheric aerosols, with rather small number densities in the middle stratosphere. LOAC measurements reveal concentrations mainly below $1 \mathrm{~cm}^{-3}$ for particles greater than $0.2 \mu \mathrm{m}$, which corresponds to the expected situation for background aerosols in the stratosphere (Deshler et al., 2003; Renard et al., 2010b).

The typology in the stratosphere (Fig. 18, top) indicates that almost all particles below $2 \mu \mathrm{m}$ in diameter are liquid; nevertheless, solid (carbon) particles were sometimes detected for the smallest size (Fig. 18, bottom). The presence of such a transient carbonaceous particles layers was previously mentioned by Renard et al. (2008) from balloon measurements but were also often detected from aircraft measurements (Blake and Kato, 1995; Murphy et al., 2007). The origin of these particles could be biomass burning, aircraft traffic, but also "smoke" particles coming for meteoritic disintegration (Murphy et al., 1998; Neely et al., 2011).

Finally, for most of the vertical sounding flights, LOAC has detected a few particles greater than $10 \mu \mathrm{m}$ in the strato-

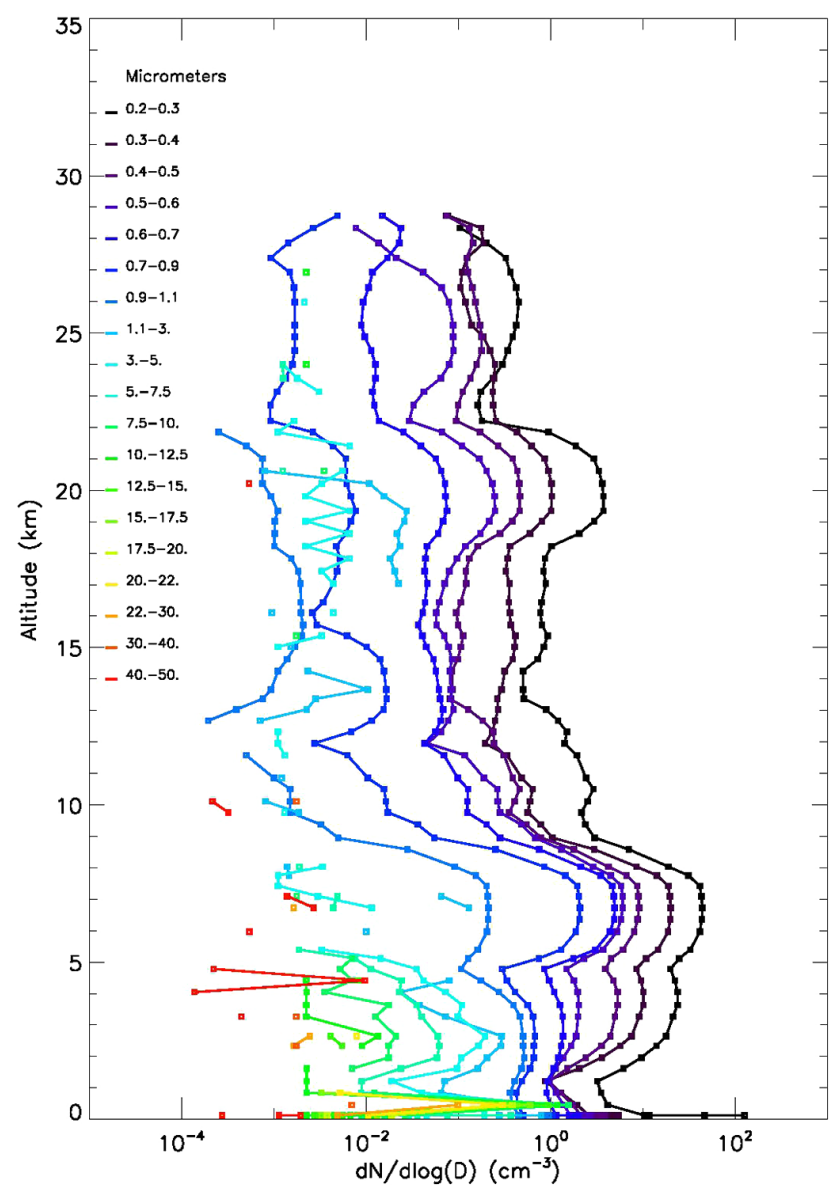

Figure 17. LOAC flight under a meteorological balloon from Aire-sur-l'Adour (France) on 12 August 2015 between 9:50 and 11:40 UT during the VOLTAIRE-LOAC campaign; the uncertainty (at $1 \sigma$ ) is of about $\pm 20 \%$ for concentrations higher than $10^{-1} \mathrm{~cm}^{-3}$ up to $\pm 60 \%$ for concentrations lower than $10^{-2} \mathrm{~cm}^{-3}$. The stratospheric aerosol content is low, since no major volcanic eruption has occurred recently.

sphere. These detections are similar to the ones obtained by the DUSTER balloon-borne particle collector (Ciucci et al., 2011; Della Corte, 2012) and can be attributed to interplanetary dust (Brownlee, 1985).

The counting can be converted to extinction, using Mie calculations and assuming spherical particles. Excluding the regions of local aerosol concentrations enhancements, the averaged retrieved values are in agreement with conventional satellite data for background conditions (e.g. SAGE and GOMOS data, Neely et al., 2011; Salazar et al., 2013), typically of a few $10^{-4} \mathrm{~km}^{-1}$ in the $20-25 \mathrm{~km}$ altitude range and a few $10^{-5} \mathrm{~km}^{-1}$ at around $30 \mathrm{~km}$. Of course, more flights will be necessary to be able to statistically compare the LOAC and satellite retrieved extinctions. 

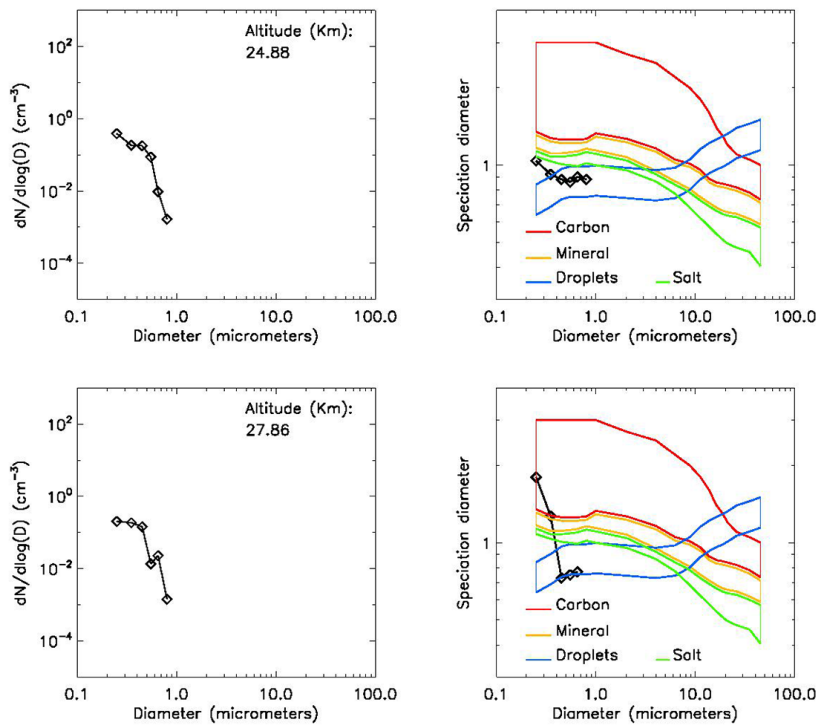

Figure 18. Examples of size distributions and typology at two altitudes for the 12 August 2015 LOAC flight from Aire-sur-l'Adour (France); the uncertainties for concentrations are the same as in Fig. 17; the sizes of the dots represent the error bars for the typology. At an altitude of $\sim 25 \mathrm{~km}$, the typology indicates mainly liquid particles; at an altitude of $\sim 28 \mathrm{~km}$, the typology also indicates the presence of carbonaceous particles at the smallest sizes.

\section{Discussion}

Due to its industrial production, a large number of copies of LOAC are available. They can be operated at ground, in aerial conditions, and can conduct measurements up to the middle stratosphere. LOAC ability to estimate the main nature of aerosols can be used to better distinguish between the various layers of aerosols having different origins.

Because of its small weight, the LOAC gondola, including PTU sensors, can be launched easily with meteorological balloons, without specific infrastructure when the wind speed at ground is below around $10 \mathrm{~m} \mathrm{~s}^{-1}$; in this case only two people are necessary. Tens of flights per year could be conducted from different locations to locally monitor the tropospheric and stratospheric aerosol content at different latitudes. Also, several flights per week can be conducted to study specific events (as an example, 9 flights to be discussed in a forthcoming paper were conducted in 5 days in June 2013 from Minorca, Spain, during the ChArMEx campaign to study a sand plume over the Mediterranean Sea). It is thus possible to better analyse the time and spatial variability of the aerosol content in the free atmosphere, in terms of size distribution and main nature; this new measurements strategy is similar to the one already conducted with ozone soundings. Using forecast trajectories, the balloon trajectory can be estimated before the flight to optimize the probability of a safe recovery of the gondola. As an example, the recovery success was of $95 \%$ for the flights conducted in France from Aire-sur-l' Adour and Ury since 2014. Thanks to LOAC robustness, the recovered instrument can be re-used several times.

The large set of measurements obtained in the various geophysical conditions presented above has allowed us to obtain original results on the aerosol content in the different parts of the atmosphere. Using a tethered balloon, we have started to better document the urban pollution from the ground up to the middle of the boundary layer, and to determine the evolution of the size distribution and the nature of the particles with altitude. In the free troposphere, the balloon measurements inside several desert dust plumes have shown the unexpected persistence of large coarse particles of more than $15 \mu \mathrm{m}$ and up to several tens of $\mu \mathrm{m}$ in diameter. The analysis of the LOAC and balloon housekeeping data during these flights indicate the presence of strong electrostatic fields inside the plume (but not outside) that slightly disrupted the electronics. Ulanowski et al. (2007) observed polarization effects in a dust plume over the Canary Island that they attributed to alignment of particles due to an electric field. Also, Nicoll et al. (2010) has reported that there is a charge present within layers of Saharan dust, from two balloon soundings performed above Cape Verde Islands. These fields might explain the sustained levitation of these large particles, but this hypothesis needs further experimental studies.

In the lower and middle stratosphere, LOAC has confirmed the presence of layers of carbonaceous particles. Local transient concentrations enhancements at around an altitude of $30 \mathrm{~km}$ were probably observed in the past with the STAC aerosol counter (Renard et al., 2010b), but the nature and origins of particles are not yet fully determined. Such enhancements seems to be also present in some flights performed during the ChArMEx and the VOLTAIRE-LOAC campaigns, but need yet further analysis to be confirmed.

Finally, the large size range detection of LOAC has allowed us to detect unambiguously the presence of interplanetary grains and meteoritic debris. All these first results need further flights to better document the complex content of the aerosol content in the various parts of the atmosphere.

\section{Conclusions and perspectives}

LOAC is simultaneously involved in different projects. The LOAC ground-based and tethered balloon measurements at the Observatoire Atmosphérique Generali (Paris) will continue. The detailed analysis of the variation in concentration and the nature of the urban aerosols with altitude is still in progress, in particular during strong pollution events. Measurements at SIRTA (Palaiseau) will also continue for the detection of fog events and the time evolution of their size distribution, and for the monitoring of sub-urban particles.

LOAC is also involved in different projects for the monitoring and the identification of tropospheric and stratospheric 
aerosols, using meteorological balloons and large stratospheric large balloons (zero pressure and super-pressure). In the frame of the VOLTAIRE-LOAC project, dedicated to the long-term monitoring of stratospheric aerosols, flights under meteorological balloons are conducted every 2 weeks from Aire-sur-l'Adour (south-west of France) and Ury (southeast of Paris) since January 2014. Such a strategy of recurrent balloon flights is suitable to capture events like volcanic eruptions and to derive long-term trends in the stratospheric aerosol content. Additional flights will be conducted from Reykjavik (Iceland) and Ile de la Réunion (France, Indian Ocean) to better document the latitudinal dependence of stratospheric aerosols and to identify the evolution of their nature with altitude. Some flights will be also be conducted from Iceland during dedicated campaigns for the study of the vertical transport of frequently re-suspended volcanic dust (Dagsson-Waldhauserova et al., 2013), and in the case of future major volcanic events. Also, the large number of flights performed each year will allow us to better estimate the mean concentrations of large particles in the middle atmosphere. Thus we expect to provide soon an estimate of the interplanetary dust input in the upper atmosphere.

The LOAC flights on-board UAVs have started, mainly for the measurements of urban pollution and the characterization of the aerosol sources, but other applications are under study.

LOAC is now involved in the Strateole-2 project for the study of the equatorial upper troposphere and the lower stratosphere during balloon flights lasting several months (probably after 2018).

Finally, the LOAC concept and design (in terms of weight and electric consumption) are well suited for measurements in various planetary atmospheres (like Mars, Saturn and Ti$\tan )$. Some electronic improvements have started recently to propose a LOAC instrument that can comply with the spatial constraints, in particular in terms of very low temperature, and robustness to vibrations and radiations.

\section{Data availability}

The LOAC data from UAV are shared properties of the Fly $\mathrm{N}$ Sense Company and the LOAC team and are available on request, as well as the LOAC data obtained from the Vienna/Paris tethered balloons.

The LOAC ChArMEx data are available on the ChArMEx database at http://mistrals.sedoo.fr/ChArMEx/. The user must register before having access to the data. The VOLTAIRE-LOAC balloon flight data are available at the ETHER database: http://www.pole-ether.fr/.

Acknowledgements. The LOAC project was funded by the French National Research Agency's ANR ECOTECH. The instrument and the gondola are built by Environnement-SA and MeteoModem companies. The balloons flights of the MISTRALS/ChArMEx campaign were funded and performed by the French Space Agency
CNES. The various copies of LOAC used in the campaigns were funded with the support of CNES, INSU-CNRS and the French VOLTAIRE-LOAC Labex (Laboratoire d'Excellence ANR10-LABX-100-01).

The authors want to thank the EGU Atmospheric Sciences Division, especially Division President Oksana Tarasova, for their involvement in the LOAC measurements during 2013 EGU General Assembly, and the CNES launching team for the support and dedication that ensured the success of the LOAC flights. OMP/SEDOO in Toulouse and ICARE thematic centre in Lille are gratefully acknowledged for their support to ChArMEx browse products and database. L. Gonzales and C. Deroo from Laboratoire d'Optique Atmosphérique are acknowledged for the NAScube product based on EUMETSAT MSG/SEVIRI data.

This work is in memory of Jean-Luc Mineau.

Edited by: O. Dubovik

Reviewed by: three anonymous referees

\section{References}

Ammann, C. M., Meehl, G. A., Washington, W. M., and Zender, C. S.: A monthly and latitudinally varying volcanic forcing dataset in simulations of 20th century climate, Geophys. Res. Lett., 30, 1657, doi:10.1029/2003GL016875, 2003.

Bergametti, G., Gomes, L., Remoudaki, E., Desbois, M., Martin, D., and Buat-Ménard, P.: Present transport and deposition patterns of African dusts to the north-western Mediterranean, in: Paleoclimatology and Paleometeorology: Modern and Past Patterns of Global Atmospheric Transport, edited by: Leinen, M. and Sarnthein, M., Kluwer Academic Publishers, Dordrecht, the Netherlands, 227-251, 1989.

Blake, D. F. and Kato, K.: Latitudinal distribution of black carbon soot in the upper troposphere and the lower stratosphere, J. Geophys. Res., 100, 7195-7202, 1995.

Brownlee, D.: Cosmic dust: collection and research, Annu. Rev. Earth Pl. Sc., 13, 147-173, 1985.

Brunekreef, B. and Holgate, S. T.: Air pollution and health, Lancet, 360, 1233-1242, 2002.

Chazette, P., Bocquet, M., Royer, P., Winiarek, V., Raut, J.-C., Labazuy, P.,Lardier, M., and Cariou, J.-P.: Eyjafjallajökull ash concentrations derived from both lidar and modelling, J. Geophys. Res.-Atmos., 117, D00U14, doi:10.1029/2011JD015755, 2012.

Ciucci, A., Palumbo, P., Brunetto, R.,Della Corte, V., De Angelis, S., Rotundi, A., Rietmeijer, F. J. M., Zona, E., Colangeli, L., Esposito, F., Mazzotta Epifani, E., Mennella, V., Inarta, S., Peterzen, S., Masi, S., and Ibba, R.: DUSTER (Dust in the Upper Stratosphere Tracking Experiment and Retrieval) - Preliminary results, Memorie della Societa Astronomica Italiana Supplement, 6, 119-124, 2011.

Dagsson-Waldhauserova, P., Arnalds, O., and Olafsson, H.: Longterm frequency and characteristics of dust storm events in Northeast Iceland (1949-2011), Atmos. Environ., 77, 117-127, 2013.

Della Corte, V., Palumbo, P., Rotundi, A., De Angelis, S., Rietmeijer, F. J. M., Bussoletti, E., Ciucci, A., Ferrari, M., Galluzzi, V., and Zona, E.: In situ collection of refractory dust in the upper 
stratosphere: the DUSTER Facility, Space Sci. Revs., 169, 159180,2012

Denjean, C., Cassola, F., Mazzino, A., Triquet, S., Chevaillier, S., Grand, Bourrianne, T., Momboisse, G., Sellegri, K., Schwarzenbock, A., Freney, E., Mallet, M., and Formenti, P.: Size distribution and optical properties of mineral dust aerosols transported in the western Mediterranean, Atmos. Chem. Phys., 16, 1081-1104, doi:10.5194/acp-16-1081-2016, 2016.

Deshler, T., Hervig, M. E., Hofmann, D. J., Rosen, J. M., and Liley, J. B.: Thirty years of in situ stratospheric aerosol size distribution measurements from Laramie, Wyoming $\left(41^{\circ} \mathrm{N}\right)$ using balloon-borne instruments, J. Geophys. Res., 108, 4167, doi:10.1029/2002JD002514, 2003.

Dulac, F., Buatménard, P., Arnold, M., Ezat, U., and Martin, D.: Atmospheric input of trace metals to the western Mediterranean Sea: factors controlling the variability of atmospheric concentrations, J. Geophys. Res., 92, 8437-8453, 1987.

Dulac, F., Bergametti, G., Losno, R., Remoudaki, E., Gomes, L., Ezat, U., and Buatménard, P.: Dry deposition of mineral aerosol particles in the marine atmosphere: Significance of the large size fraction, Precipitation Scavenging and Atmosphere-Surface Exchange, edited by: Schwartz, S. E. and Slinn W. G. N., Hemisphere, Richland, Wa, 2, 841-854, 2002.

Ethé, C., Basdevant, C., Sadourny, R., Appu, K. S., Harenduprakash, L., Sarode, P. R., and Viswanathan, G.: Air mass motion, temperature and humidity over the Arabian Sea and western Indian Ocean during the INDOEX intensive phase, as obtained from a set of superpressure drifting balloons, J. Geophy. Res., 107, 8023, doi:10.1029/2001JD001120, 2002.

Foret, G., Bergametti, G., Dulac, F., and Menut, L.: An optimized particle size bin scheme for modeling mineral dust aerosol, J. Geophys. Res., 111, D17310, doi:10.1029/2005JD006797, 2006.

Formenti, P., Rajot, J. L., Desboeufs, K., Saïd, F., Grand, N., Chevaillier, S., and Schmechtig, C.: Airborne observations of mineral dust over western Africa in the summer Monsoon season: spatial and vertical variability of physico-chemical and optical properties, Atmos. Chem. Phys., 11, 6387-6410, doi:10.5194/acp-11-6387-2011, 2011.

Hanson, D. R., Ravishankara, A. R., and Solomon, S.: Heterogeneous reactions in sulphuric acid aerosols: a framework for model calculation, J. Geophys. Res., 99, 3615-3629, 1994.

Hanson, D. R., Ravishankara, A. R., and Lovejoy, E. R.: Reactions of $\mathrm{BrONO}_{2}$ with $\mathrm{H}_{2} \mathrm{O}$ on submicron sulphuric acid aerosol and implication for the lower stratosphere, J. Geophys. Res., 101, 9063-9069, 1996.

Holton, J., Pyle, J., and Curry, J. (Eds.): Encyclopedia of Atmospheric Sciences, 1st Edn. V1-6, Elsevier, Amsterdam, the Netherlands, ISBN: 978-0-12-227090-1, 2632 pp., 2003.

Karagulian, F., Belis, C. A., Dora, C. F. C., Prüss-Ustün, A. Bonjour, S., Adair-Rohani, H., and Amann, M.: Contributions to cities' ambient particulate matter (PM): A systematic review of local source contributions at global level, Atmos. Environ., 120, 465483, 2015

Kaufman, Y. J., Tanré, D., and Boucher, O.: A satellite view of aerosols in the climate system, Nature, 419, 215-223, 2002.

Lurton, T., Renard, J.-B., Vignelles, D., Jeannot, M., Akiki, R., Mineau, J.-L., and Tonnelier, T.: Light scattering at small angles by atmospheric irregular particles: modelling and laboratory measurements, Atmos. Meas. Tech., 7, 931-939, doi:10.5194/amt-7-931-2014, 2014.

Mallet, M., Dulac, F., Formenti, P., Nabat, P., Sciare, J., Roberts, G., Pelon, J., Ancellet, G., Tanré, D., Parol, F., Denjean, C., Brogniez, G., di Sarra, A., Alados-Arboledas, L., Arndt, J., Auriol, F., Blarel, L., Bourrianne, T., Chazette, P., Chevaillier, S., Claeys, M., D’Anna, B., Derimian, Y., Desboeufs, K., Di Iorio, T., Doussin, J.-F., Durand, P., Féron, A., Freney, E., Gaimoz, C., Goloub, P., Gómez-Amo, J. L., Granados-Muñoz, M. J., Grand, N., Hamonou, E., Jankowiak, I., Jeannot, M., Léon, J.-F., Maillé, M., Mailler, S., Meloni, D., Menut, L., Momboisse, G., Nicolas, J., Podvin, T., Pont, V., Rea, G., Renard, J.-B., Roblou, L., Schepanski, K., Schwarzenboeck, A., Sellegri, K., Sicard, M., Solmon, F., Somot, S., Torres, B., Totems, J., Triquet, S., Verdier, N., Verwaerde, C., Waquet, F., Wenger, J., and Zapf, P.: Overview of the Chemistry-Aerosol Mediterranean Experiment/Aerosol Direct Radiative Forcing on the Mediterranean Climate (ChArMEx/ADRIMED) summer 2013 campaign, Atmos. Chem. Phys., 16, 455-504, doi:10.5194/acp-16-455-2016, 2016.

Menut, L., Mailler, S., Siour, G., Bessagnet, B., Turquety, S., Rea, G., Briant, R., Mallet, M., Sciare, J., and Formenti, P.: Analysis of the atmospheric composition during the summer 2013 over the Mediterranean area using the CHARMEX measurements and the CHIMERE model, Atmos. Chem. Phys. Discuss., 14, 23075 23123, doi:10.5194/acpd-14-23075-2014, 2014.

Miffre, A., David, G., Thomas, B., Abou Chacra, M., and Rairoux, P.: Interpretation of Accurate UV Polarization Lidar Measurements: Application to Volcanic Ash Number Concentration Retrieval, J. Atmos. Ocean. Tech., 29, 558-568, 2012.

Muñoz, O. and Volten, H.: Experimental light scattering matrices from the Amsterdam Light Scattering Database, in: Light Scattering Reviews, Part 1, edites by: Kokhanovsky, A. A., Springer Berlin Heidelberg, Germany, 3-29, 2006.

Murphy, D. M., Thomson, D. S., and Mahoney M. J.: In situ measurements of organics, meteoritic material, mercury, and other elements in aerosols at 5 to 19 kilometers, Science, 282, 16641669, 1998.

Murphy, D. M., Cziczo, D. J., Hudson, P. K., and Thomson, D. S.: Carbonaceous material in aerosol particles in the lower stratosphere and tropopause region, J. Geophys. Res., 112, D04203, doi:10.1029/2006JD007297, 2007.

Neely, R. R., English, J. M., Toon, O. B., Solomon, S., Mills, M., and Thayer, J. P.: Implications of extinction due to meteoritic smoke in the upper stratosphere, Geophys. Res. Lett., 38, L24808, doi:10.1029/2011GL049865, 2011.

Nicoll, K. A., Harrison, R. G., and Ulanowski, Z.: Observations of Saharan dust layer electrification, Environ. Res. Lett., 6, 014001, doi:10.1088/1748-9326/6/1/01/014001, 2011.

Renard, J.-B., Brogniez, C., Berthet, G., Bourgeois, Q., Gaubicher, B., Chartier, M., Balois, J.-Y., Verwaerde, C., Auriol, F. Francois, P., Daugeron, D., and Engrand, C.: Vertical distribution of the different types of aerosols in the stratosphere: Detection of solid particles and analysis of their spatial variability, J. Geophys. Res., 113, D21303, doi:10.1029/2008JD010150, 2008.

Renard, J.-B., Thaury, C., Mineau, J.-L., and Gaubicher, B.: Smallangle light scattering by airborne particulates: EnvironnementS.A. continuous particulate monitor, Meas. Sci. Technol., 21, 085901 doi:10.1088/0957-0233/21/8/085901, 2010a. 
Renard, J.-B., Berthet, G., Salazar, V., Catoire, V., Tagger, M., Gaubicher, B., and Robert, C.: In situ detection of aerosol layers in the middle stratosphere, Geophys. Res. Lett., 37, L20803, doi:10.1029/2010GL044307, 2010b.

Renard, J.-B., Dulac, F., Berthet, G., Lurton, T., Vignelles, D., Jégou, F., Tonnelier, T., Jeannot, M., Couté, B., Akiki, R., Verdier, N., Mallet, M., Gensdarmes, F., Charpentier, P., Mesmin, S., Duverger, V., Dupont, J.-C., Elias, T., Crenn, V., Sciare, J., Zieger, P., Salter, M., Roberts, T., Giacomoni, J., Gobbi, M., Hamonou, E., Olafsson, H., Dagsson-Waldhauserova, P., Camy-Peyret, C., Mazel, C., Décamps, T., Piringer, M., Surcin, J., and Daugeron, D.: LOAC: a small aerosol optical counter/sizer for ground-based and balloon measurements of the size distribution and nature of atmospheric particles - Part 1: Principle of measurements and instrument evaluation, Atmos. Meas. Tech., 9, 1721-1742, doi:10.5194/amt-9-1721-2016, 2016.

Ryder, C. L., Highwood, E. J., Lai, T. M., Sodemann, H., and Marsham, J. H.: Impact of atmospheric transport on the evolution of microphysical and optical properties of saharan dust, Geophys. Res. Lett., 40, 10, 2433-2438, doi:10.1002/grl.50482, 2013.

Salazar, V., Renard, J.-B., Hauchecorne, A., Bekki, S., and Berthet, G.: A new climatology of aerosols in the middle and upper stratosphere by alternative analysis of GOMOS observations during 2002-2006, Int. J. Remote Sens., 34, 4986-5029, doi:10.1080/01431161.2013.786196, 2013
Thieuleux, F., Moulin, C., Bréon, F. M., Maignan, F., Poitou, J., and Tanré, D.: Remote sensing of aerosols over the oceans using MSG/SEVIRI imagery, Ann. Geophys., 23, 3561-3568, doi:10.5194/angeo-23-3561-2005, 2005.

Ulanowski, Z., Bailey, J., Lucas, P. W., Hough, J. H., and Hirst, E.: Alignment of atmospheric mineral dust due to electric field, Atmos. Chem. Phys., 7, 6161-6173, doi:10.5194/acp-7-6161-2007, 2007.

Weinzierl, B., Sauer, D., Esselborn, M., Petzold, A., Veira, A., Rose, M., Mund, S.,Wirth, M., Ansmann, A., Tesche, M., Gross, S., and Freudenthaler, V.: Microphysical and optical properties of dust and tropical biomass burning aerosol layers in the Cape Verde region-an overview of the airborne in situ and lidar measurements during SAMUM-2, Tellus B, 63, 589-618, doi:10.1111/j.1600-0889.2011.00566.x, 2011.

Wendisch, M., Coe, H., Baumgartner, D., Brenguier, J.-L., Dreiling, V., Fiebig, M., Formenti, P., Hermann, M., Krämer, M., Levin, Z., Maser, R., Mathieu, E., Nacass, P., Noone, K., Osoborne, S., Schneider, J., Schütz, L., , Schwartzennböck, A., Stratmann, F., and Wilson, J. C.: Aircraft particle inlets: State-of-the-art and future needs, B. Am. Meteorol. Soc., 85, 89-92, 2004. 